\title{
Teacher education in inclusive education
}

\section{Tirri, Kirsi}

SAGE Reference

2017-07-01

Tirri , K \& Laine , S 2017 , Teacher education in inclusive education . in D J Clandinin \& J Husu (eds), The SAGE Handbook of Research on Teacher Education . vol. Volume 2 , SAGE Reference , Los Angeles , pp. 761-776 . https://doi.org/10.4135/9781526402042.n44

http://hdl.handle.net/10138/311883

https://doi.org/10.4135/9781526402042.n44

unspecified

acceptedVersion

Downloaded from Helda, University of Helsinki institutional repository.

This is an electronic reprint of the original article.

This reprint may differ from the original in pagination and typographic detail.

Please cite the original version. 


\section{Teacher education in inclusive education}

\section{Kirsi Tirri and Sonja Laine}

\section{Introduction}

In recent decades, educational systems all around the world have changed radically, and classrooms have become more diverse than ever. In the course of this change, demands on schools and on teachers have become increasingly complex (Saloviita, 2015), and teachers are expected to meet the varied needs of diverse learners (VanTassel-Baska \& Stambaugh, 2005; Dixon, Yssel, McConnell, \& Hardin, 2014). Pressures on teacher education have therefore increased, since teachers of the future need to be educated to overcome and cope with these challenges. In this chapter, our emphasis is on teacher education and how student diversity is challenging teacher-student relationships.

We begin by describing the context of inclusive education. We provide the widest possible definition of inclusion, and we emphasize the important role of teacher education in the development of inclusive practices. National contexts differ in the way that teachers are educated and school systems organized (Florian \& Rouse, 2009). As an example of context, we use Finland to illustrate ways in which a country which has been acclaimed as a leader in teacher education is instructing teachers to meet the needs of diverse learners in inclusive classrooms.

Teachers make a difference, and their pedagogical thinking is a core element in making educational decisions. According to Hattie (2009), the teacher and the nature of 
teacher-student relationships are among the most critical aspects of a student's learning experience. Effective teachers are those "using particular teaching methods, teachers with high expectations for all students, and teachers who have created positive studentteacher relationship" (Hattie, 2009, p. 126). Furthermore, the beliefs necessary for successful inclusive education are the idea "that all students can learn and progress" and "achievement for all is changeable and not fixed" (Hattie, p. 218). These ideas reflect the growth mindset-belief identified by Carol Dweck (2000), namely, an attitude that intelligence, personality, and abilities can be developed and changed.

In this chapter, the didactic triangle (Herbart, 1835) provides a conceptual framework for teachers' pedagogical thinking and for a curriculum of inclusive teacher education. Pedagogical thinking includes both rational and intuitive reasoning in teachers' practical knowledge (Kansanen, Tirri, Meri, Krokfors, Husu, \& Jyrhmä, 2000). We discuss interactive relationships in teaching with emphasis on the pedagogical relation between a teacher and a student as well as on the didactic relation between a teacher and student's learning to illuminate the concrete teaching-studyinglearning process in which inclusive education is actualized. Teachers' values, beliefs, and attitudes to diverse learners have a powerful effect on their pedagogical and didactical relations (Kansanen et al. 2000), and educating teachers for inclusion should therefore reflect these. We discuss inclusion from the perspective of pedagogical practices as well. We present differentiated teaching and inclusive pedagogy as an optional pedagogical basis for educating different kinds of learners. These components should be at the core of the teacher education curriculum. 


\section{A context for inclusive education}

\section{Defining the concept of inclusion}

Defining the concept of inclusion is a challenging task (Armstrong et al., 2011; Moberg \& Savolainen, 2003). As Armstrong et al. (2011, p. 31) have stated, "It is not simply that inclusion means different things to different people but rather that inclusion may end up meaning everything and nothing at the same time." The various definitions of inclusion can be divided between narrow and broad (Ainscow et al., 2006). Narrow definitions promote the inclusion of specific groups of students, such as disabled students. Broad definitions, on the other hand, focus on diversity and how schools respond to the diversity of all students (Armstrong et al., 2011, p. 31).

In the context of education, inclusion has often been connected exclusively with disability and special education (Arnesen, Mietola, \& Lahelma, 2007; Miles \& Singal, 2010), which yields a narrow definition. Thus, in the minds of many people, inclusion refers solely to a particular group of children, namely, students with special learning needs (Smith, 2006). However, as the following example from the UNESCO Salamanca Statement shows, inclusion reaches further:

The guiding principle that informs this framework is that schools should accommodate all children regardless of their physical, intellectual, social, linguistic or other conditions. This should include disabled and gifted children, street and working children, children from remote or nomadic populations, children from linguistic, ethnic, or cultural minorities and children from other disadvantage or marginalized areas and groups. (UNESCO, 1994) 
In this article we use a broad definition whereby inclusion is defined as nondiscriminatory quality education for all (Saloviita, 2015; UNESCO, 2009).

\section{Teacher education for inclusion}

The Salamanca Statement, as well as other generalized definitions developed by international agencies, may help the initial discussion, but these are less helpful when practitioners attempt to make sense of inclusive education (Miles \& Singal, 2010). Furthermore, the existence of inclusive policies or the discourse of inclusion does not mean that inclusion functions in practice (Kivirauma, Klemelä, \& Rinne, 2006). Consequently, the crucial role of teachers in providing quality education is widely acknowledged (Florian \& Rouse, 2009), and teachers have been considered key persons in making inclusion a reality (Moberg \& Savolainen, 2003; de Boer, Pijl, \& Minnaert, 2011). Thus, teacher education, especially pre-service education, is believed to play a central role in achieving truly inclusive schools (Saloviita, 2015; Allday et al., 2013; Forlin, 2010).

There are differences between countries in how teacher education is organized. Typically, inclusive education for teachers is offered either as part of initial training or as ongoing professional learning for in-service teachers, and it involves both course work and teaching practice (Forlin, 2010). However, much of teachers' learning takes place in actual practice through experience and interaction with colleagues, students, and others (Booth et al., 2003). Nevertheless, whenever there is discussion about formal teacher education, there is a need for judgment about what teachers must be prepared to think and do (Darling-Hammond, 2008; Kansanen et al., 2000). As demands on teachers 
have increased, basic content knowledge is no longer seen as adequate. As the WHO World Report on Disability (2011, p. 222) states: “The principles of inclusion should be built into teacher training programmes, which should be about attitudes and values not just knowledge and skills.”

Where inclusion is concerned, there seem to be two distinct, but overlapping strands regarding the content of teacher education (Florian \& Rouse, 2009). On the one hand, there are those who claim that there is a specific set of knowledge and skills for working with "special children." On the other hand, there are those who maintain that, since inclusion involves more than "special children," teacher education should focus on improving learning and teaching for all. (Florian \& Rouse, 2009) Florian and Rouse (2009, p. 596) have suggested that there is a need to move beyond the debate; they have formulated the tasks of teacher education to "prepare people to enter a profession, which accepts individual and collective responsibility for improving the learning and participation for all children." Furthermore, there is a need for teachers who are confident in their own ability to teach all students and to be willing to participate and be engaged in the educational reform of inclusion (Forlin, 2010).

Besides the question of content, there is also the question of how teacher education should be organized. Historically, as students' different needs have been addressed through different forms of provisions, educators have realized that this specialist knowledge should be offered to teachers in separate programs. For example, special education teachers have been taught separately from classroom teachers. Similarly, whenever need for multicultural education has been acknowledged, a new, separate course has been added to teacher education programs. (Florian, Young, \& Rouse, 2010) However, because there is some indication that these kinds of separate 
programs only reinforce teachers' views of the students they are responsible for teaching, and because many educational practices across settings are similar for different types of learners, the way in which teachers are prepared to work in schools today should be reconsidered and restructured (Florian, Young, \& Rouse, 2010).

Most of the earlier research on teachers and inclusion has concentrated on teachers' attitudes toward inclusion, their beliefs, and their teaching strategies. However, little is known about what exactly teachers need to know in order to teach in an inclusive school (Florian \& Black-Hawkins, 2011). Furthermore, research on how best to prepare teachers for inclusive education is still scarce (Florian, Young, \& Rouse, 2010).

\section{Teacher education for inclusion: Case example from Finland}

In the last decade, Finnish teacher education has received more and more international attention, thanks especially to the excellent results Finnish students have achieved on the OECD's Programme for International Student Assessment (PISA) since the year 2000. Good PISA achievement results together with high quality teacher education have made Finland as an exemplary country in the field of education and in training to teachers from countries all over the world (Tirri, 2014).

Universities in Finland have a high degree of autonomy in designing their curricula. As a result, there is no detailed "curriculum of teacher education" for all universities. However, there are certain principles and general outlines followed by all institutions of teacher education. Currently, teacher education in Finland is based on the idea of an autonomous and professional teacher who continues to develop throughout 
his/her working career and on the ideal of life-long learning. The goal of teacher education is to produce pedagogically-thinking teachers who can combine research findings about teaching with the profession's practical challenges. Teachers' thinking is pedagogical when it is intentional and directed toward student learning. In order to think pedagogically, a teacher has to be aware of his/her values and beliefs, formulate goals for his/her teaching and give justifications for this decision-making (Kansanen et al., 2000). Hence, reflection in action and reflection on action are important skills in becoming a pedagogically-thinking teacher (Schön, 1987), and these are highlighted in teacher education in Finland. For example, in teaching practice at the University of Helsinki, the aim is to educate a reflective teacher, one who examines, frames, and attempts to solve the dilemmas of classroom practice, is aware of and questions the assumptions and values he or she brings to teaching, is attentive to the institutional and cultural contexts in which he or she teaches, takes part in curriculum development, is involved in school change efforts, and takes responsibility for his or her own professional development (Jyrhämä \& Maaranen, 2012, 109). These emphases mean that reflective practice is present in both theoretical studies and teaching practice with the goal being to educate teachers who can combine theoretical and practical knowledge in their work.

The country's educational policy provides the values and restrictions on inclusive education that teachers and teacher educators should advocate. Finland is one of the Nordic welfare states in which equality and inclusiveness are the main guiding values in educational policy (Arnesen, Mietola, \& Lahelma, 2007; Tirri \& Kuusisto, 2013). The equality has been specifically manifested in care for the weakest students, such as children with learning difficulties (Tirri \& Kuusisto, 2013).The principle has 
been that teaching methods should be chosen in a such way as to consider students' individual characteristics, needs, and interests (Tirri \& Kuusisto, 2013), an approach addressed both in the Finnish constitution (731/1999) and in the Basic Education Act (628/1998). Furthermore, differentiation is emphasized as the pedagogical basis of teaching (Finnish National Board of Education [FNBE], 2011; 2014). According to the newest Finnish national core curriculum (FNBE, 2014), education should be developed in accordance with inclusive principles.

\section{Teacher education for inclusive education}

A good teacher is capable of pedagogical thinking, and this should be the aim of teacher education for inclusive education. In this chapter we use the didactic triangle to provide a conceptual framework for teacher's pedagogical thinking and for a curriculum of inclusive teacher education. The didactic triangle illustrates how the teaching-studyinglearning process is based on the interaction between the teacher, the student, and the content (Herbart, 1835).

In the didactic triangle the teacher's relationship with the student is called the pedagogical relation, which is asymmetrical in nature since "in the pedagogical relation the teacher has something that the students do not yet have" (Kansanen \& Meri, 1999, p. 112). The teacher's relation to content indicates the teacher's expertise, passion, and knowledge of the subject matter. In the German research tradition, "subject didactics" (Fachdidaktik) (Kansanen \& Meri, 1999) and in the Anglo-Saxon research tradition, "pedagogical content knowledge" (Shulman, 1987) mean a combination of expertise in subject content and pedagogical competence (Kuusisto \& Tirri, 2014). The relationship 
between the teacher and the student's studying and learning process is referred to as the didactic relation. The teacher's goal is to nurture this relationship in such a way that the student achieves the aims of the curriculum. Thus, the didactic relation is manifested through the individual's studying process, which the teaching can influence and should focus on the most (Kansanen \& Meri, 1999). The teacher can help the student find meaning in the subject matter with purposeful teaching; learning can thus become personally significant (Hopmann, 2007).

The didactic triangle includes all the necessary interactive components that contribute to successful inclusive education. It is essential to teach future teachers exactly how the pedagogical relation and didactical relation established in the teachingstudying-learning process is affected by their knowledge, skills, attitudes, and values about inclusion and how these contribute to the effectiveness of the inclusive education they practice.

\section{Pedagogical relation}

In the pedagogical relation between a teacher and a student, the teacher is the adult with the authority to teach, guide, and evaluate the student. The teacher is also a professional whose work is guided by the ethical codes for teachers and by the curriculum established in the educational institute where the teaching takes place. In classrooms, the teacher is responsible for many pedagogical relations at the same time, which indicates a need to reflect on the needs of different students with the goal of helping them to learn as effectively as possible. In order to establish good pedagogical relations with students, a teacher needs the skills to reflect on his or her own values and attitudes to these different learners. 
Reflective teaching is acknowledged as one possible approach for preparing teachers with the necessary attributes to implement inclusive practices for all children (Sharma, 2010; Jordan, Schwartz, \& McGhie-Richmond, 2009). Reflective teachers question their beliefs and practices, evaluate events, and alter their teaching behaviour based on craft, research, and ethical knowledge (Sharma, 2010). The starting point should be pre-service teachers' past experiences during their schooling and their beliefs about teaching (Sharma, 2010). Without this reflection, they will not be able to examine their beliefs critically or change them (Sharma, 2010). In practice, this reflective teaching includes such components as evaluating personal teaching philosophy; effective reasoning (what happened, why did it happen, what might it mean, what are the implications for my practice); collaborative problem solving; and identification, evaluation, and use of evidence-based practices (Sharma, 2010). In addition, teachers should be guided to reflect on their attitudes, beliefs, and values connected with inclusion. Next, we consider these attitudes, beliefs and values in a more detailed manner.

\section{Teachers' attitudes and beliefs}

It is generally seen that in order to address students' differing needs and abilities, teachers should have the attitudes and skills that can lead to positive changes in the students' academic and social behavior (Allday et al., 2013). It has been suggested that teachers' negative attitudes is one of the factors hindering successful inclusive practices (De Boer, Pijl, \& Minnaert, 2011). Accordingly, teachers' attitudes to inclusion have 
been one of the most frequently examined areas in inclusive education (Chambers \& Forlin, 2010).

The review of earlier research on teachers' attitudes toward inclusion reveals that teachers mostly have positive attitudes to inclusion in general (Avramidis, Bayliss, \& Burden, 2000; Avramidis \& Norwich, 2002; Moberg \& Savolainen, 2003; Allan, 2010). However, their attitudes toward the practice of inclusion are more skeptical (Moberg, \& Savolainen, 2003; de Boer et al., 2011; Farrell, Dyson, Polat, Hutcheson, \& Gallannaugh, 2007). They might, for example, have doubts about how inclusion affects the achievement of pupils with SEN and their peers (Farrell et al., 2007), or they see that in practice the premises do not support inclusion (Avramidis \& Norwich, 2002), or they might feel that their skills for implementing inclusion are inadequate (Allan, 2010; Burstein, Sears, Wilcoxen, Cabello, \& Spagna, 2004; deBoer, Pjil, \& Minnaert, 2011). Furthermore, teachers' high self-efficacy toward inclusive education has been found to be related to more positive attitudes (Sharma, Loreman, \& Forlin, 2011; Savolainen, Engelbrecht, Nel, \& Malinen, 2012). Special education teachers (Moberg \& Savolainen, 2003) and teachers with favorable experiences of inclusion have been found to be more positive toward inclusion as well (Moberg \& Savolainen, 2003). Furthermore, there is some indication that the type and the severity of disability affect teachers' attitudes (Avramidis et al., 2000; Avramidis \& Norwich, 2002; Evans \& Lunt, 2002; Farrell et al., 2007; Moberg \& Savolainen, 2003). For example, emotional and behavioral difficulties cause more concerns than other types of SEN (Avramidis et al., 2000; Avramidis \& Norwich, 2002; Evans \& Lunt, 2002; Farrell et al., 2007), and teachers are most supportive of the physical or sensory disorders (Evans \& Lunt, 2002). However, 
most of this research has been done from the perspective of the inclusion of special educational needs (SEN) students.

Foundations for more positive attitudes toward inclusion can be built in teacher education programs (Killoran, Woronko, \& Zaretsky, 2014). Since attitudes can influence intentions and behavior in the classroom (Chamber \& Forlin, 2010), one aim of teacher education should be about reflecting beliefs and attitudes of pre-service teachers in order to improve more positive attitudes toward inclusion. There is a need to develop teachers for new ways of believing that all children are worthy of education, all children can learn, teachers have the capacity to make the difference and such work is their responsibility (Rouse, 2010). Carol Dweck's (2000) theory of mindsets, defined as beliefs that individuals hold about their most basic qualities and abilities, can be regarded as a promising theory to use for improving teachers' beliefs of every child's capacity to learn. People with a growth mindset (i.e., an incremental theory of abilities) believe that intelligence, personality, and abilities can be developed. People with a fixed mindset (i.e., an entity theory of abilities) believe that these basic qualities are static and unalterable. Mindsets act as mechanisms behind several motivational and learningrelated processes and have relevance for all learners. (Dweck, 2000) While a fixed mindset leaves students vulnerable to negative feedback and can lead to avoidance of challenges, a growth mindset helps students take risks and see possible failures as learning opportunities (Dweck, 2000). Furthermore, although mindsets are quite stable, they are alterable through educational interventions (e.g., Aronson, Fried \& Good, 2002; Yearger, Trzesniewski, Tirri, Nokelainen, \& Dweck, 2011). Thus, educators' role in orienting students to the idea of increasing their abilities through effort is seen as crucial (Dweck, 2009). 
Moreover, the results of earlier attitude research have indicated the importance of offering fieldwork experiences and contacts to pre-service teachers during their teacher education (Chambers \& Forlin, 2010; Brownlee \& Carrington, 2000). It has been found that the most effective results are achieved when fieldwork is combined with formal instruction (Campbell, Gilmore, \& Guskelly, 2003).

Teachers'values

The emphasis on teacher professionalism has prompted an increasing number of countries to publish formalized codes of ethics for teachers (Terhart, 1998). In the United States, teachers have had formalized codes of ethics for 60 years. For example, in 1975, the NEA (National Education Association) Code stressed the self-control or self-commitment of the teaching profession. In these codes, the profession defined commitments to students and to the teaching profession. European countries published formalized codes of ethics for teachers much later.

For example, in Finland the ethical principles for teachers were published for the first time in 1998 by the Trade Union of Education (Tirri, 2010). These principles defined the values behind teachers' ethics. These clearly defined values, which are based on humanistic psychology, are human worth, honesty, justice, and freedom. Furthermore, the principles defined the values in the context of pedagogical interactions relevant to a teacher's work. The values should be reflected in the relationships between the teacher and the pupil, as well as between the teacher and his/her colleagues. The principles also provide guidance in the development of a teacher's personality and relationship to work and society (Trade Union of Education in Finland, 2010; Tirri, 
2010). Moreover, teachers are trusted in Finland and given a great deal of professional freedom in curriculum design, teaching methods, and learning materials (Sahlberg, 2011). This autonomy challenges teachers' ethical conduct and makes them reflect on the bases of their professional ethics.

Professional ethics also include reflection on the values and virtues of a teacher (Lovat, Toomey, Clement, Pring, \& Noddings. 2010). According to empirical studies, teachers cannot separate their own moral character from their professional selves. The stance of teachers' moral character functions as a moral approach in teachers' reasoning, guiding how they interact with pupils and giving the young hope for the future. The professional approach in teachers' reasoning includes rules and principles that guide their pedagogical practice and decision-making. These rules and principles build teachers' professional character in their practical knowing (Tirri, Husu, \& Kansanen, 1999). Empirical research on Finnish teachers has indicated that, in critical situations in their work, these teachers value professional commitment in terms of caring and cooperation (Hanhimaki \& Tirri, 2008, 2009; Tirri, 1999). Furthermore, teachers in Finland individually tailor and personalize their curricula for their students with special needs. This emphasis on caring for students with special needs has produced good learning results, even with those struggling with socially disadvantaged backgrounds. Taken together, an atmosphere of caring, an effort to meet the needs of individual students from diverse backgrounds, and respect for different families have created conditions for success and the emotional well-being of students within the context of schools (Hanhimäki \& Tirri, 2009). These findings have implications for teacher education curricula and suggest increasing content that encourages future teachers to reflect on the values and the beliefs that underlie their professional ethics 
and their attitudes toward students from diverse backgrounds.

\section{Didactical relation}

The goal of teaching is for a teacher to establish a didactic relation to a student's learning. In this relation, the teacher needs to find ways to motivate the student to study and learn the content of the curriculum (Kuusisto \& Tirri, 2014). In inclusive education, the challenge for a teacher is to find different methods and approaches for students whose content knowledge, abilities, and study skills, among other things, differ from each other. Furthermore, there is evidence that "teachers who accept responsibility for teaching a wide diversity of students, and feel confident in their instructional and management skills, can successfully implement inclusive programmes" (Avramidis \& Norowich, 2002, p. 140). Thus, in order to make inclusion work, teachers need different skills and pedagogies (Forlin, 2010; Winter, 2006).

A highly critical aspect of inclusive teacher education is to break the traditional idea of a homogeneous approach to teaching, which is no longer seen as adequate (Forlin, 2010). In fact, the idea that there is a one-size-fits-all curriculum that meets the needs of most students should be abandoned (e.g. Subban, 2006; Tomlinson, 1999; Tomlinson, 2001; Dixon et al., 2014; Ferguson, 2008). Instead, a curriculum that is meaningful, interesting, and engaging for every student (Ferguson, 2008) together with instructional practices that enable all students to learn and develop (Roy, Guan, \& Valois, 2013) is required. To achieve that, teachers first need to diagnose their own skills in assessing students' current level of performance. Second, the teachers need to find the materials and methods to teach the student in the zone of proximal development identified by Vygotsky (1978). According to this pedagogical approach, the teaching 
should start from familiar contents and proceed to the unknown, beginning with the simple things and ending up with more complex issues. In this process, the teacher also needs knowledge of different ways to meet the needs of diverse learners in an inclusive classroom. Thus, instead of offering pre-service teachers content knowledge only, preservice teachers need preparation in pedagogy and practice (Forlin, 2010). Their educational programs should prepare them to plan and execute teaching that is suitable for a wide range of students. In this chapter we present two different pedagogical approaches to inclusive practices: differentiation and inclusive pedagogy.

The practice of differentiation is rooted in a student-centered philosophy or ethic of teaching (Tomlinson \& Imbeau, 2010). It is seen as an approach to teaching in which teachers address students' different needs, abilities, interests, and learning profiles (Tomlinson, 1999, 2001; Subban, 2006). Differentiation is guided by the general principles of respectful tasks, flexible grouping, and ongoing assessment and adjustment (Tomlinson, 1999; Subban, 2006). While differentiating, teachers proactively modify curricula, teaching methods, resources, learning activities, and students' products (Tomlinson et al., 2003). Furthermore, every student's learning is assisted in a way appropriate to that student's level (Dixon et al., 2014; Tomlinson, 1999). The goal of differentiation is to maximize every student's learning opportunity (Tomlinson et al., 2003), as well as the student's individual success and growth (Dixon et al., 2014). By means of differentiation, support and appropriate modifications for students with disabilities is possible, as well as appropriate challenges for those students who already excel. However, there is some indication that teachers do not implement differentiation on a regular basis (cf. Latz et al., 2009, Archambault et al., 1993; Westberg, 
Archambault, \& Brown, 1997), or they do not necessarily use evidence-based differentiation practices (Laine \& Tirri, 2016).

Inclusive pedagogy is a relatively new concept, intended to avoid problems and stigma associated with marking some learners as different (Florian \& Black-Hawkins, 2011). While typical inclusive practices include the idea of providing for all, yet differentiating for some, inclusive pedagogy is about everyone (Florian \& BlackHawkins, 2011). The teacher's role is to create options and optimal conditions, while student are allowed and trusted to make decisions about their own learning (Florian \& Black-Hawkins, 2011; Black-Hawkins \& Florian, 2012). Furthermore, it is considered important to reject deterministic beliefs that ability is fixed along with the idea that the presence of some students will hold back the progress of others (Black-Hawkins \& Florian, 2013). This approach calls for seeing difficulties as professional challenges, for example, instead of seeing deficits in learners, and it calls for being continuously committed to the professional development of more inclusive practices (Black-Hawkins \& Florian, 2013).

\section{Conclusions}

In this chapter, we have presented the teacher with his or her values, beliefs, attitudes, and pedagogical knowledge as the key factor in inclusive education. The nature of interactive relationships in teaching, pedagogical relations, and didactic relations have been identified as pre-requisites to successful inclusive education. Teachers need to have the motivation and skills to establish pedagogical relations with diverse learners, as well as the knowledge of different teaching methods and practices in order to motivate different students to study and learn the curriculum content. These issues 
should be acknowledged and taught in teacher education programs and in curriculum planning all over the world. The goal of teacher education should be to produce a reflective teacher who can reflect on the values, beliefs, and attitudes that guide his or her pedagogical thinking and teaching practice, including teaching for inclusion. The growth mindset (also called an incremental theory of abilities) discussed in this chapter can guide teachers and teacher educators to believe that intelligence, personality, and abilities can be developed. This kind of mindset would provide the best possible starting point for educating different learners in inclusive settings.

In addition to reflecting beliefs, attitudes, and values, teachers need knowledge about the successful inclusion of different students, such as students with special education needs and gifted students. This kind of knowledge should be provided in teacher education curricula by means of practical plans and opportunities for trying different teaching strategies with diverse student populations. Without these kinds of training opportunities, it is difficult for teachers to include diverse students in mainstream education (Avramidis \& Norwich, 2002). Research-based teacher education acknowledges practices that are evidence-based from inclusive schools (Burstein et al., 2004). The teacher education curriculum should pay special attention to teachers' pedagogical content knowledge on how to educate different learners and practice teaching for inclusion in different subjects and contexts.

In their comparative chapter on the history of initial teacher education programs in the United States, Chile, South Africa, Singapore and Finland, Placier et al. (2015) recognize the harm of past inequities as well as the economic benefits of a more educated population in their countries. As democracies, all of these countries face the challenge of preparing teachers to provide more equitable learning opportunities. This is 
one reason why teacher education curricula should not neglect the importance of addressing the political and economic issues related to inclusive education. Many times, financial resources are allocated on the basis of political decisions. Schools and teachers also lack resources to meet the needs of all their students, and many times they have to choose whose needs to prioritize. Furthermore, teacher education curricula always reflect the culture of each nation. Each country should reflect on its own history and the cultural roots underlying their educational system to understand better the current policies and practices concerning inclusive education. In teacher education curricula, these historical and cultural roots should be discussed and reflected on so that future teachers understand the bigger context of the education to which they will contribute. 


\section{References}

Ainscow, M., Booth, T., Dyson, A., Farrell, P., Frankham, J., Gallannaugh, F., Howes, A., \& Smith, R. (2006). Improving schools, developing inclusion. London: Routledge.

Ainscow, M. (2007). From special education to effective schools for all: a review of progress so far. In L. Florian (Ed.), The Sage Handbook of Special Education, pp. 146-159.

Allan, J. (2010). Questions of inclusion in Scotland and Europe. European Journal of Special Needs Education, 25(2), 199-208.

Allday, R.A., Neilsen-Gatti, S., \& Hudson, T.M. (2013). Preparation for inclusion in teacher education pre-service curricula. Teacher Education and Special Education, 36(4), 298-311.

Archambault, F., Westberg, K., Brown, S., Hallmark, B., Emmons, C., \& Zhang, W. (1993). Regular classroom practices with gifted students: Results of a national survey of classroom teachers Differentiation: A Literature Review 137 (Research monograph 93102). Storrs: University of Connecticut, National Research Center on the Gifted and Talented.

Armstrong, D., \& Armstrong, A.C., \& Spandagou, I. (2011). Inclusion: by choice or by chance? International Journal of Inclusive Education, 15(1), 29-39.

Arnesen, A-L., Mietola, R., \& Lahelma, E. (2007). Language of inclusion and diversity: policy discourses and social practices in Finnish and Norwegian schools. International Journal of Inclusive Education, 11(1), 97-110. 
Aronson, J., Fried, C.B., \& Good, C. (2002). Reducing the effects of stereotype threat on African American college students by shaping theories of intelligence. Journal of Experimental Social Psychology, 38, 113-125.

Avramidis, E., Bayliss, P., \& Burden, R. (2000). Student teachers' attitudes towards the inclusion of children with special educational needs in the ordinary school. Teaching and Teacher Education, 16, 277-293.

Avramidis, E., \& Norwich, B. (2002). Teachers' attitudes towards integaration/inclusion: a review of the literature. European Journal of Special Needs Education, 17(2), 129-147.

Basic Education Act (628/1998). Retrieved March 30, 2015, from http://www.finlex.fi/en/laki/kaannokset/1998/en19980628.pdf

Black-Hawkins, K., \& Florian, L. (2012). Classroom teachers' craft knowledge of their inclusive practice. Teacher and Teaching, 18(5), 567-584.

Booth, T., Nes, K., \& Stromstad, M. (2003). Developing inclusive teacher education. London: Routledge.

Brownlee, J., \& Carrington, S. (2000). Opportunities for authentic experience and reflection: a teaching programme designed to change attitudes towards disability for pre-service teachers. Support for Learning, 15(3), 99-105.

Burstein, N., Sears, S., Wilcoxen, A., Cabello, B., \& Spagna, M. (2004). Moving toward inclusive practices. Remedial and Special Education, 25(2), 104-116.

Chambers, D., \& Forlin, C. (2010). Initial teacher education and inclusion: a triad of inclusive experiences. In C. Forlin (Ed.), Teacher Education of Inclusion, pp. 74-83. New York, NY: Routledge. 
Campbell, J., Gilmore, L., \& Cuskelly, M. (2003). Changing student teachers' attitudes towards disability and inclusion. Journal of Intellectual \& Developmental Disability, 28(4), 369-379.

Darling-Hammond, L. (2008). The case of university-based teacher education. In M. Cochran-Smith, S. Freiman-Nemser, D.J. McIntyre, \& K. E. Demers (Eds.), Handbook of Research on Teacher Education (3 ${ }^{\text {rd }}$ ed.), pp. 333-346.

De Boer, A., Pijl, S. J., \& Minnaert, A. (2011). Regular primary schoolteachers' attitudes towards inclusive education: a review of literature. International Journal of Inclusive Education, 15(3), 331-353.

Dixon, F. A., Yssel, N., McConnell, J. M., \& Hardin, T. (2014). Differentiated instruction, professional development, and teacher efficacy. Journal for the Education of the Gifted, 37(2), 111-127.

Dweck, C. S. (2000). Self-theories: Their role in motivation, personality and development. New York, London: Psychology Press.

Dweck, C.S. (2009). Self-theories and lessons for giftedness: a reflective conversation. In T. Balchin, B. Hymer, \& D. Matthews (Eds.). The Routledge International Companion to Gifted Education (pp- 308-316). USA: Routledge.

Evans, J. \& Lunt, I. (2002). Inclusive education: are there limits? European Journal of Special Needs Education, 17(1), 1-14.

Farrell, P., Dyson, A., Polat, F., Hutcheson, G., \& Gallannaugh, F. (2007). Inclusion and achievement in mainstream school. European Journal of Special Needs Education, 22(2), 131-145. 
Ferguson, D.L. (2008). International trends in inclusive education: the continuing challenge to teach each one and everyone. European Journal of Special Education Needs Education, 23(2), 109-120.

Finnish Constitution (1999/731). Retrieved March 30, 2015, from http://www.finlex.fi/fi/laki/kaannokset/1999/en19990731.pdf

FNBE (2011). Perusopetuksen opetussuunnitelman perusteiden muutokset ja täydennykset 2010. [Amendments and Additions to the National Core Curriculum for Basic Education 2010]. Tampere, Finland: Tampereen Yliopistopaino.

FNBE (2014). Perusopetuksen opetussuunnitelman perusteet. [National Core Curriculum in Basic Education 2014]. Tampere, Finland: Suomen yliopistopaino.

Florian, L. \& Black-Hawkins, K. (2011). Exploring inclusive pedagogy. British Educational Research Journal, 37(5), 813-828.

Florian, L., \& Rouse, M. (2009). The inclusive practice project in Scotland: Teacher education for inclusive education. Teaching and Teacher Education, 25, 594601.

Florian, L., Young, K., Rouse, M. (2010). Preparing teachers for inclusive and diverse educational environments: studying curricular reform in an initial teacher education course. International Journal of Inclusive Education, 14(7), 709-722.

Forlin, C. (2010). Reframing teacher education for inclusion. In C. Forlin (Ed.), Teacher Education of Inclusion, pp. 3-12. New York, NY: Routledge.

Hanhimäki, E., \& Tirri, K. (2009). Education for ethically sensitive teaching in critical incidents at school. Journal of Education for Teaching 35, 107-121. 
Hanhimäki, E., \& Tirri, K. (2008). The moral role and characteristics of Finnish urban school principals. Journal of Research in Character Education, 6(1), 53-65.

Hattie, J. (2009). Visible learning: a synthesis of over 800 meta-analyses relating to achievement. London and New York: Routledge.

Herbart, J. F. (1835). Umriss pädagogischer Vorlesungen von Johan Friedrich Herbart.Verausgegeben und mit erläuternden Anmerkungen versehen von Hermann Wendt [Compendium of Pedagogical Lectures by Johan Friedrich Herbart, compiled and edited by Hermann Wendt]. Leipzig: Verlag von Philipp Reclam jun.

Jordan, A., Schwartz, E., \& McGhie-Richmont, D. (2009). Preparing teachers for inclusive classroom. Teaching and Teacher Education, 25, 535-542.

Jyrhämä, R., \& Maaranen, K. (2012). Research Orientation in a Teacher's Work. In H. Niemi, A, Toom \& Kallioniemi, A. Niemi, H. (Eds.), Miracle of Education, pp. 97-112. Rotterdam/Taipei/Boston: Sense Publishers.

Kansanen, P., \& Meri, M. (1999). The Didactic Relation in the Teaching-StudyingLearning Process. In B. Hudson, F. Buchenberger, P. Kansanen, \& H. Seel (Eds.), Didaktik/Fachdidaktik as Science(-S) of the Teaching Profession, pp.107-116. Umeå: TNTEE.

Kansanen, P., Tirri, K., Meri, M., Krokfors, L., Husu, J., \& Jyrhämä, R. (2000). Teachers' pedagogical thinking: Theoretical landscapes, practical challenges. (American University Studies XIV Education Vol. 47). New York: Peter Lang. Killoran, I., Woronko, D., \& Zaretsky, H. (2014). Exploring preservice teachers' attitudes towards inclusion. International Journal of Inclusive education, 18(4), $427-442$. 
Kivirauma, J., Klemelä, K., \& Rinne, R. (2006). Segregation, integration, inclusion the ideology and reality in Finland. European Journal of Special Needs Education, 21(2), 117-133.

Kuusisto, E. \& Tirri. K. (2014). The core of religious education: Finnish student teachers' pedagogical aims. Journal of Beliefs and Values 35(2).

Laine, S. \& Tirri, K. (2016). How Finnish Elementary School Teachers Meet the Needs of Their Gifted Students. High Ability Studies, e-publication ahead of print.

Latz, A. O., Speirs Neumeister, K. L., Adams, C. M., \& Pierce, R.L. (2009). Peer coaching to improve classroom differentiation: perspectives from project CLUE. Roeper Review, 31(1), 27-39.

Lovat, T., Toomey, R., Clement, N., Pring, N., \& Noddings, N. (2010). International Handbook on values education and student wellbeing, New York: Springer.

Miles, S., \& Singal, N. (2010). The education for all and inclusive education debate: conflict, contradiction or opportunity. International Journal of Inclusive Education, 14(1), 1-15.

Moberg, S., \& Savolainen, H. (2003). Struggling for inclusive education in the North and the South: Educators' perceptions on inclusive education in Finland and Zambia. International Journal of Rehabilitation Research, 26(1), 21-31.

Placier, P., Letseka, M., Seroto, J. , Loh, J., Montecinos, C., Vásquez, N. \& Tirri, K. (2015). The History of Initial Teacher Preparation in International Contexts. In Loughran, J. \& Hamilton, M. (Eds.). Handbook of Teacher Education, pp. 2268. Singapore: Springer.

Rouse, M. (2010). Reforming initial teacher education: a necessary but not sufficient condition for developing inclusive practice. In C. Forlin (Ed.), Teacher 
Education of Inclusion, pp. 48-55. New York, NY: Routledge.

Roy, A., Guay, F., \& Valois, P. (2013). Teaching to address diverse learning needs: development and validation of a differentiated instruction scale. International Journal of Inclusive Education, 17(11), 1186-1204.

Sahlberg, P. (2011). Finnish lessons: What can the world learn from educational change in Finland? New York: Teachers College Press.

Saloviita, T. (2015). Measuring pre-service teachers' attitudes towards inclusive education: Psychometric properties of the TAIS scale. Teaching and Teacher Education, 52, 66-72.

Savolainen, H., Engelbrecht, P., Nel, M., \& Malinen, O-P. (2012). Understanding teachers' attitudes and self-efficacy in inclusive education: Implications for preservice and in- service teacher education. European Journal of Special Needs Education, 27(1), 51-68.

Schön, D. (1987). Educating the Reflective Practitioner. San Francisco: Jossey-Bass.

Sharma, U. (2010). Using reflective practices for the preparation of pre-service teachers for inclusive classrooms. In C. Forlin (Ed.), Teacher Education of Inclusion, pp. 102-111. New York, NY: Routledge.

Sharma, U., Loreman, T., \& Forlin, C. (2011). Measuring teacher efficacy to implement inclusive practices. Journal of Research in Special Education Needs, 12(1), 110.

Smith, C.M.M. (2006). Principles of inclusion: implications for able learners. In C.M.M. Smith (Ed), Including Gifted and Talented: Making Inclusion work for more gifted and able learners. London \& New York: Routledge. 
Subban, P. (2006). Differentiated instruction: a research basis. International Education Journal, 7(7), 935-947.

Terhart, E. (1998). Formalised codes of ethics for teachers: Between professional autonomy and administrative control. European Journal of Education, 33(4), 433-444.

Tirri, K. 2014. The last 40 years in Finnish teacher education. The Journal of the Education for Teaching, 40 (5), 600-609.

Tirri, K. (2010). Teachers' values underlying their professional ethics. In T. Lovat, R. Toomey, N. Clement, R. Pring, \& N. Noddings (Eds.), International Handbook on values education and student wellbeing, pp. 153-163. New York: Springer.

Tirri, K. (1999). Teachers' perceptions of moral dilemmas at school. Journal of Moral Education, 28(1), 31-47.

Tirri, K. \& Kuusisto, E. (2013). How Finland serves gifted and talented pupils. The Journal for the Education of Gifted 36(1), 84-96.

Tirri, K., Husu, J., \& Kansanen, P. (1999). The epistemological stance between the knower and the known. Teaching and Teacher Education, 15, 911-922.

Tomlinson, C. A. (2001). How to Differentiate Instruction in Mixed-ability Classrooms (2nd ed.). Upper Saddle River, NJ: Pearson Education.

Tomlinson, C. A. (1999). The Differentiated Classroom: Responding to the Needs of All Learners. Upper Saddle River, NJ: Pearson Education.

Tomlinson, C. A., Brighton, C., Hertberg, H., Callahan, C. M., Moon, T. R., Brimijoin, K., Conover, L. A., \& Reynolds, T. (2003). Differentiating instruction in response to student readiness, interest, and learning profile in academically 
diverse classrooms: a review of literature. Journal for the Education of the Gifted, 27(2), 119-145.

Tomlinson, C.A., \& Imbeau, M.B. (2010). Leading and managing a differentiated classroom. Alexandria, VA: ASCD.

Trade Union of Education in Finland. (2010). Code of ethics for Finnish teachers. Helsinki: Trade Union of Education in Finland.

UNESCO. (1994). The Salamanca statement and framework for action on special needs education. In World conference on special needs education: access and quality. Salamanca, Spain, June 7e10, 1994.

UNESCO. (2009). Policy guidelines on inclusion in education. Paris: UNESCO.

Retrieved from http://unesdoc.UNESCO.org/images/0017/001778/177849e.pdf. VanTassel-Baska, J., \& Stambaugh, T. (2005). Challenges and possibilities for serving gifted learners in regular classroom. Theory into Practice, 44(3), 211-217.

Vygotsky, L.S. (1978). Mind and society: The development of higher psychological processes. Cambridge, MA: Harvard University Press.

Westberg, K. L., Archambault, F. X, \& Brown, S. W. (1997). A survey of classroom practices with third and fourth grade students in the United States. Gifted Education International, 12(1), 29-33.

WHO. (2011). World report on disability. Retrieved from http://www.who.int/disabilities/world_report/2011/report.pdf

Winter, E.C. (2006). Preparing new teachers for inclusive schools and classrooms. Support for Learning, 21(2), 85-91. 
Yeager, D., Trzesniewski, K.H., Tirri, K., Nokelainen, P., \& Dweck, C.S. (2011). Adolescents' implicit theories predict desire for vengeance after remembered and hypothetical peer conflicts. Developmental Psychology, 47(4), 1090-1107. 